\title{
Taxonomically Different Co-Microsymbionts of a Relict Legume, Oxytropis popoviana, Have Complementary Sets of Symbiotic Genes and Together Increase the Efficiency of Plant Nodulation
}

\author{
Vera I. Safronova, ${ }^{1,+}$ Andrey A. Belimov, ${ }^{1}$ Anna L. Sazanova, ${ }^{1}$ Elizaveta R. Chirak, ${ }^{1}$ Alla V. Verkhozina, ${ }^{2}$ \\ Irina G. Kuznetsova, ${ }^{1}$ Evgeny E. Andronov, ${ }^{1}$ Jan V. Puhalsky, ${ }^{1}$ and Igor A. Tikhonovich ${ }^{1,3}$ \\ ${ }^{1}$ All-Russia Research Institute for Agricultural Microbiology (ARRIAM), 196608, St. Petersburg, sh. Podbelskogo 3 , Russian \\ Federation; ${ }^{2}$ Siberian Institute of Plant Physiology and Biochemistry (SIPPB), 664033, Irkutsk, P.O.Box 1243, Russian \\ Federation; and ${ }^{3}$ Saint Petersburg State University, Department of Genetics and Biotechnology, 199034, St. Petersburg, \\ Universitetskaya Emb. 7/9, Russian Federation
}

Accepted 28 February 2018.

\begin{abstract}
Ten rhizobial strains were isolated from root nodules of a relict legume Oxytropis popoviana Peschkova. For identification of the isolates, sequencing of $r r s$, the internal transcribed spacer region, and housekeeping genes $r e c A, g \ln I I$, and $r p o B$ was used. Nine fast-growing isolates were Mesorhizobium-related; eight strains were identified as $M$. japonicum and one isolate belonged to $M$. kowhaii. The only slow-growing isolate was identified as a Bradyrhizobium sp. Two strains, M. japonicum Opo-242 and Bradyrhizobium sp. strain Opo-243, were isolated from the same nodule. Symbiotic genes of these isolates were searched throughout the whole-genome sequences. The common nodABC genes and other symbiotic genes required for plant nodulation and nitrogen fixation were present in the isolate Opo-242. Strain Opo-243 did not contain the principal nod, nif, and fix genes; however, five genes (nodP, nodQ, nifL, nolK, and noeL) affecting the specificity of plant-rhizobia interactions but absent in isolate Opo-242 were detected. Strain Opo-243 could not induce nodules but significantly accelerated the root nodule formation after coinoculation with isolate Opo-242. Thus, we demonstrated that taxonomically different strains of the archaic symbiotic system can be co-microsymbionts infecting the same nodule and promoting the nodulation process due to complementary sets of symbiotic genes.
\end{abstract}

${ }^{\dagger}$ Corresponding author: Vera I. Safronova; E-mail: v.safronova@ rambler.ru

Funding: This work was supported by the Russian Science Foundation (grant 16-16-00080 for microbiology, molecular and bioinformatics work, grant 17-76-30016 for photography of plants and nodules, grant 14-2600094 for soil analysis and grant 17-14-01363 for conducting pot experiment). Deposition of strains in the Russian Collection of Agricultural Microorganisms collection was supported by the Federal Agency of Scientific Organizations (the Program for the Development of Bioresource Collections).

All sequences have been deposited to the National Center for Biotechnology Information GenBank database, the whole-genome sequences under accession numbers MZXX00000000, for isolate M. japonicum Opo242, and MZXW00000000, for the isolate Bradyrhizobium sp. strain Opo243 and rrs sequences under accession numbers MF661781 to MF661790.

*The $\boldsymbol{e}$-Xtra logo stands for "electronic extra" and indicates that three supplementary figures are published online.

(c) 2018 The American Phytopathological Society
Symbiosis has been recognized as a fundamental process in the coevolution of species that is accompanied by an increase in the specificity of symbiotic interactions (Provorov and Vorobyev 2011; Tikhonovich and Provorov 2009). But the genetic basis for such specificity is still poorly understood because of the lack of adequate experimental models. In this respect, the promising models for studying the evolution of plant-microbial relationships are symbiotic systems of relict legume species.

Information about strains isolated from root nodules of the relict legume Vavilovia formosa, which is the closest relative of the extinct ancestor of the tribe Fabeae (Kenicer et al. 2009; Sinjushin et al. 2009), was recently published (Safronova et al. 2014). It was shown that $V$. formosa had a wide range of nodulating strains belonging to different families, such as Rhizobiaceae, Phyllobacteriaceae, and Bradyrhizobiaceae (Safronova et al. 2014; 2015b) and a new species, Bosea vaviloviae, was described (Safronova et al. 2015a). Then, a collection of taxonomically different microsymbionts of legumes Oxytropis triphylla, O. popoviana, O. tragacanthoides, Hedysarum zundukii, Astragalus chorinensis, and Glycyrrhiza uralensis belonging to the MiocenePliocene relics (Malyschev 2006; Turuta et al. 2015) and originated from the Baikal Lake region was created (Safronova et al. 2017a).

The impact of natural rhizobial diversity and resulting multipartite interactions between symbionts on plant growth is currently poorly understood. The influence of inoculation with single- and multi-strains on the productivity of two Australian Acacia species (A. salicina and A. stenophylla) interacting with highly diverse communities of rhizobia was recently estimated (Barrett et al. 2015). It was shown that the multi-strain treatments had a negative effect on plant growth and were not able to enhance plant productivity through mechanisms of either complementarity or selection. As a result, the 'antagonism hypothesis' was supported, according to which the presence of multiple rhizobial strains in the rhizosphere leads to strong competition between strains with different levels of nitrogenfixing activity, the formation of low- or ineffective symbiosis, and decrease in plant productivity. However, the data describing multipartite interactions between the plant and different rhizobial co-microsymbionts that jointly participate in the formation of the same nodule have not yet been published.

Earlier, four pairs of strains with different growth rates were isolated in approximately equal proportion from root nodules of O. triphylla (Safronova et al. 2017b). Identification of these 
strains by $16 \mathrm{~S}$ ribosomal RNA (rRNA) gene sequencing showed that one strain of each pair belonged to the fast-growing bacteria of genus Phyllobacterium but the other strain belonged to the slow-growing bacteria of genus Bosea (Safronova et al. $2017 \mathrm{~b}$ ). Further study of these strains was postponed because of the difficulties of cultivating $O$. triphylla plants that grow in an extremely arid region, in the gnotobiotic conditions used.

The aim of this work was to study rhizobial strains isolated from the root nodules of another relict legume, Oxytropis popoviana, originating from the restricted area of Buryatia (the Baikal Lake region). Special attention was paid to the presence of different strains in the same nodule and analysis of symbiotic gene complementation by the comparison of whole genome sequences and nodulation assay.

\section{RESULTS AND DISCUSSION}

\section{Isolation of rhizobial strains in a pot experiment.}

Soil analysis showed that samples used for a pot experiment belonged to podzols type, in accordance with the World Reference Base for Soil Resources, and were characterized by low values of available $\mathrm{P}\left(5.5 \mathrm{mg} \mathrm{P}_{2} \mathrm{O}_{5} / 100 \mathrm{~g}\right)$, total $\mathrm{C}(1.9 \%)$, and total N (0.19\%). Such poor soils should favor formation of rhizobia-legume symbiosis (Tikhonovich and Provorov 2007).
Figures $1 \mathrm{~A}$ and $1 \mathrm{~B}$ show $O$. popoviana plant and root nodules obtained at the end of the pot experiment. A total of 35 nodules were collected. Most nodules were pink, suggesting the presence of leghemoglobin and nitrogen-fixing activity. Their shape corresponded to the elongate-indeterminate type of nodules (Sprent et al. 2013), usually with one branch or, rarely, two branches (Fig. 1B). Nodule size varied from 1 to $5 \mathrm{~mm}$. Nine fast-growing rhizobial strains (Opo-225, Opo-228, Opo-235, Opo-239, Opo-240, Opo-242, Opo-245, Opo-249, and Opo-324) as well as one slow-growing strain, Opo-243, were isolated from eight nodules. Colonies of fast- and slowgrowing strains appeared on yeast extract mannitol agar (Vincent 1970) supplemented with succinate at 5 and 7 days, respectively. Two strains, Opo-242 and Opo-243, differing in growth rate, were isolated from the same nodule and presented approximately in equal proportion in the amount of $10^{4}$ CFU.

\section{Identification of isolates by the analysis}

of $16 \mathrm{~S}$ rDNA, internal transcribed spacer (ITS) region, and housekeeping genes $\operatorname{rec} A, g \ln I I$, and $r p o B$.

The preliminary identification of the isolates by sequencing of the 16S rRNA gene (Table 1; Fig. 2) showed that all fastgrowing strains belonged to genus Mesorhizobium. The isolates



Fig. 1. Oxytropis popoviana plant and root nodules $\mathbf{A}$ and $\mathbf{B}$, in the pot experiment and $\mathbf{C}$ through $\mathbf{H}$, in the gnotobiotic nodulation assay after 2,4 , and 6 weeks of plant vegetation. C, E, and G, Inoculation with the isolate Opo-242 and D, F, and H, coinoculation with the isolates Opo-242 and Opo-243, after 2 (C and D), 4 (E and F), and 6 weeks ( $\mathrm{G}$ and $\mathrm{H})$. The single inoculation with the strain Opo-243 did not produce nodules. 
Opo-225, Оро-228, Opo-235, Оро-239, Opo-240, Opo-242, Opo-245, and Opo-249 formed a separate cluster at $91 \%$ bootstrap support with the type strains $M$. japonicum $\mathrm{MAFF}$ $303099^{\mathrm{T}}$ and $M$. erdmanii USDA $3471^{\mathrm{T}}$ (Fig. 2) and had 99.61 to $100 \%$ and 99.68 to $100 \%$ rrs similarity with these type strains, respectively (Table 1). However, the rrs sequence of type strain
M. erdmanii (accession number NR135857.1) was characterized by the 35 nucleotides deletion 5'-GGCAGCGAGA CCGCGAGGTCGAGCTAATCTCCAAA-3' from the 1190 position. Thus, we identified the fast-growing isolates mentioned above as a $M$. japonicum species, which was recently described for two Lotus-nodulating strains (Martínez-Hidalgo et al.

Table 1. Rrs sequence similarities between Mesorhizobium-related isolates from Oxytropis popoviana and the reference type strains

\begin{tabular}{|c|c|c|c|c|c|}
\hline \multirow[b]{3}{*}{ Isolate } & \multicolumn{5}{|c|}{$r r s$ sequence similarities $(\%)^{\mathbf{a}}$} \\
\hline & \multirow[b]{2}{*}{ M. japonicum MAFF 303099 } & \multicolumn{2}{|c|}{ M. erdmanii USDA $3471^{T}$} & \multirow[b]{2}{*}{ M. opportunistum WSM2075 ${ }^{\mathrm{T}}$} & \multirow[b]{2}{*}{ M. kowhaii ICMP $19512^{\mathrm{T}}$} \\
\hline & & Without deletion & With deletion & & \\
\hline Opo-225 & 99.86 & 99.85 & 97.35 & 99.64 & 97.85 \\
\hline Оро-228 & 100 & 100 & 97.10 & 99.79 & 98.00 \\
\hline Opo-235 & 100 & 100 & 97.49 & 99.78 & 98.00 \\
\hline Opo-239 & 99.61 & 99.68 & 97.21 & 99.38 & 97.59 \\
\hline Оро-240 & 99.85 & 99.85 & 97.31 & 99.64 & 97.91 \\
\hline Oро-242 & 100 & 100 & 97.17 & 99.80 & 98.00 \\
\hline Opo-245 & 99.71 & 99.71 & 97.48 & 99.50 & 97.77 \\
\hline Opo-249 & 100 & 100 & 97.30 & 99.77 & 97.91 \\
\hline Opo-324 & 98.11 & 98.06 & 95.56 & 98.18 & 100 \\
\hline
\end{tabular}

a The nucleotide deletion is $5^{\prime}$-GGCAGCGAGACCGCGAGGTCGAGCTAATCTCCAAA-3'.

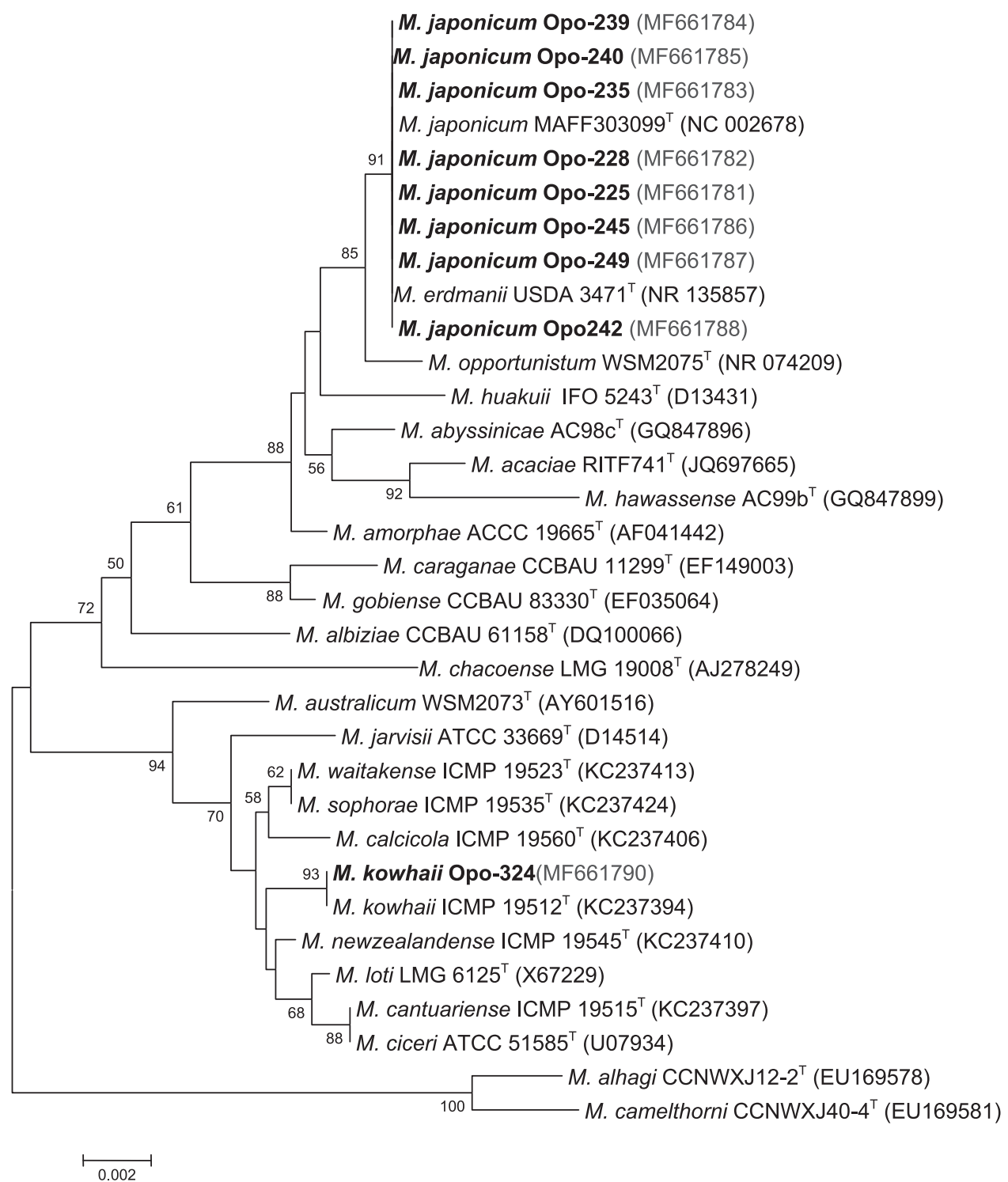

Fig. 2. Phylogenetic tree generated by the neighbor-joining method, using partial $16 \mathrm{~S}$ rRNA gene sequences (1,400 nt) of the Mesorhizobium-related isolates from Oxytropis popoviana (in bold) and closely related species. Bootstrap values more than $50 \%$ are given. Type strains are indicated by the letter T. 
2016). The isolate Opo-324 had $100 \%$ rrs similarity with the type strain M. kowhaii ICMP $19512^{\mathrm{T}}$ (Table 1) isolated from the root nodule of the Sophora microphylla plant in New Zealand (De Meyer et al. 2016).

A Rrs phylogenetic tree including the only slow-growing isolate, Opo-243 (Fig. 3), showed that this isolate belonged to genus Bradyrhizobium and was most closely related to the type strain B. diazoefficiens USDA $110^{\mathrm{T}}$, which was isolated from Glycine max and initially described as B. japonicum (Delamuta et al. 2013). However, the low bootstrap value (52\%) indicated that these two strains were quite distinct. $\operatorname{Rrs}$ similarity between isolate Opo-243 and the type strain of $B$. diazoefficiens was $99.48 \%$ (Table 2). To specify the taxonomic position of isolate Opo-243, the ITS region as well as the housekeeping genes recA, $g \ln I I$, and $r p o B$ obtained from the whole-genome sequence were analyzed (Figs. 4 and 5; Supplementary Figs. S1, S2, and S3). Unlike the rrs dendrogram, isolate Opo-243 formed the separate ITS cluster at $98 \%$ bootstrap support with type strains B. japonicum USDA $6^{\mathrm{T}}, B$. canariense $\mathrm{BTA}-1^{\mathrm{T}}$, B. . betae $\mathrm{LMG}$
$21987^{\mathrm{T}}$, B. rifense CTAW71 ${ }^{\mathrm{T}}$, and B. cytisi CTAW $11^{\mathrm{T}}$ (Fig. 4). The concatenated $r e c A, g \ln I I$, and $r p o B$ gene tree showed that the isolate Opo-243 was most closely related to the type strains B. canariense BTA $-1^{\mathrm{T}}$, B. rifense CTAW $71^{\mathrm{T}}$, and $B$. cytisi CTAW $11^{\mathrm{T}}$, yet distinct from the type strains of species $B$. diazoefficiens, $B$. japonicum, and B. betae (Fig. 5). ITS, recA, glnII, and rpoB gene similarities between the isolate Opo-243 and all type strains mentioned above are presented in Table 2. Based on the obtained data, we identified isolate Opo-243 as 'Bradyrhizobium sp.' because of the difficulty in assigning its species.

\section{Analysis of symbiotic genes of the isolates} M. japonicum Opo-242 and Bradyrhizobium sp. strain Opo-243 by whole-genome sequencing.

Symbiotic genes of the isolates Opo-242 and Opo-243 that were together present in the same nodule of $O$. popoviana were searched throughout the whole-genome sequences obtained. The common nodABC genes necessary for legume nodulation (Wais et al. 2002) and some other nod and noe genes participating



Fig. 3. Phylogenetic tree generated by the neighbor-joining method, using partial $16 \mathrm{~S}$ rRNA gene sequences (1,400 nt) of the Bradyrhizobium-related isolate Opo243 from Oxytropis popoviana (in bold) and closely related species. Bootstrap values more than $50 \%$ are given. Type strains are indicated by the letter T.

Table 2. Sequence similarities between Bradyrhizobium sp. strain Opo-243 isolated from Oxytropis popoviana and the type strains of most closely related species

\begin{tabular}{|c|c|c|c|c|c|c|}
\hline \multirow[b]{2}{*}{ Locus } & \multicolumn{6}{|c|}{ Sequence similarities (\%) } \\
\hline & $\begin{array}{l}\text { B. diazoefficiens } \\
\text { USDA } 110^{\mathrm{T}}\end{array}$ & $\begin{array}{l}\text { B. japonicum } \\
\text { USDA } 6^{\mathrm{T}}\end{array}$ & $\begin{array}{l}\text { B. canariense } \\
\text { BTA-1 }^{\mathrm{T}}\end{array}$ & B. betae LMG $21987^{T}$ & B. rifense CTAW71 ${ }^{\mathrm{T}}$ & B. cytisi CTAW11 ${ }^{\mathrm{T}}$ \\
\hline$r r s$ & 99.48 & 99.15 & 99.34 & 99.75 & 99.53 & 99.43 \\
\hline ITS & 91.96 & 91.14 & 91.75 & 95.17 & 95.69 & 94.19 \\
\hline$r e c A$ & 95.14 & 94.56 & 94.52 & 94.69 & 94.00 & 94.84 \\
\hline$g \ln I I$ & 95.32 & 96.23 & 94.11 & 94.19 & 95.91 & 95.91 \\
\hline rров & 95.83 & 95.69 & 93.51 & 95.83 & 94.72 & 96.38 \\
\hline
\end{tabular}


in biosynthesis, modification, and transport of rhizobial Nod factors (NFs) (Aoki et al. 2013; Lopez-Lara et al. 2001a and b; Perret et al. 2000) were present in isolate Opo-242 (Table 3). Isolate Opo-242 also contained nif and fix genes required for nitrogen fixation, nifHDK and nifENB genes encoding structural and catalytic components of the nitrogenase complex (Dos Santos et al. 2012), as well as fixABCX, fixNOPQ, and fixGHIS genes participating in electron transfer to nitrogenase and symbiotically essential oxidase complex (Edgren and Nordlund 2004; Fischer 1994). Strain Opo-243 did not contain the principal nod, nif, and fix genes, however, some other symbiotic genes were detected: nodNTGPQ, nifLS, fixNOPQGHISJKL, nolK, and noeL (Table 3). All symbiotic genes of isolate Opo-242 were most similar to different representatives of the genus Mesorhizobium (M. japonicum, M. loti, M. amorpha, M. huakuii, M. ciceri), while symbiotic genes

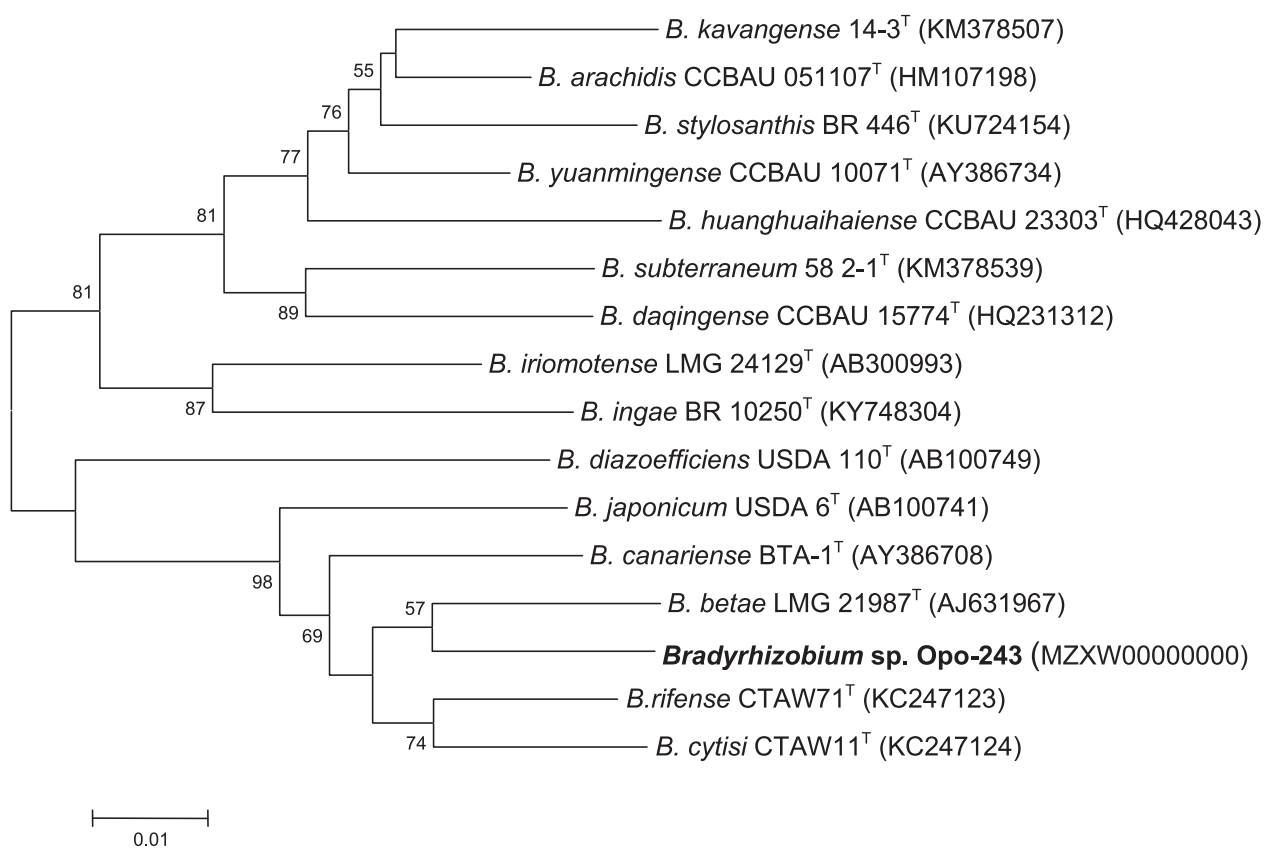

Fig. 4. Phylogenetic tree generated by the neighbor-joining method, using internal transcribed spacer region sequences of the isolate Opo-243 (in bold) and closely related species. Bootstrap values more than $50 \%$ are given. Type strains are indicated by T.

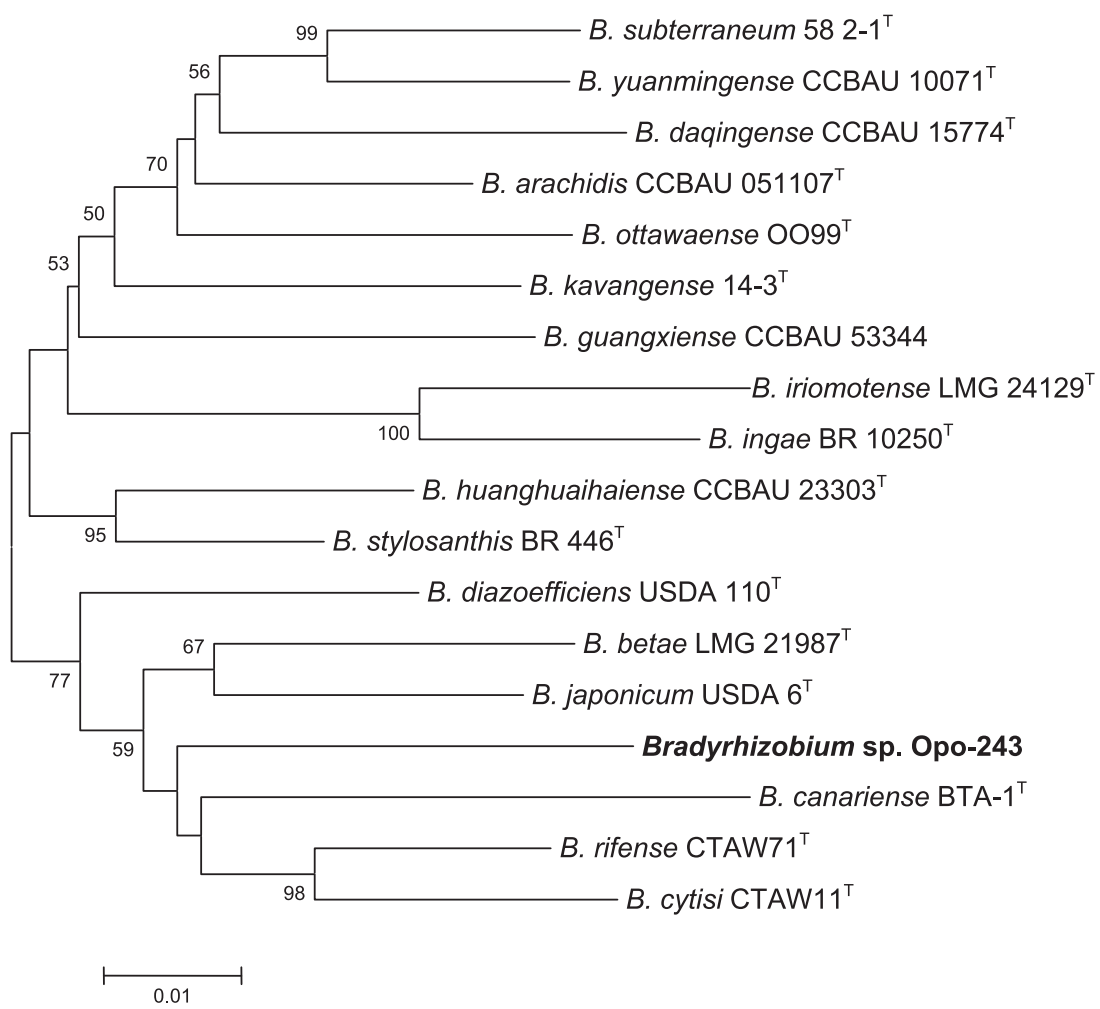

Fig. 5. Phylogenetic tree of the isolate Opo-243 (in bold) and phylogenetically related species, based on concatenated $r e c A$, glnII, and $r p o B$ gene sequences generated by the neighbor-joining method. Bootstrap values more than $50 \%$ are given. Type species are indicated by $\mathrm{T}$. 
of isolate Opo-243 were closest to B. japonicum and $B$. diazoefficiens strains. Levels of similarity between the symbiotic genes revealed and homolog sequences presented in the GenBank database ranged from 80 to $100 \%$ (data not shown). It was noted that isolate Opo-243 contained at least five genes (nodP, nodQ, nifL, nolK, and noeL) that were absent in isolate Opo-242 (Table 3). Four of them affect the specificity of plantrhizobium interactions by NF modification; nolK and noeL genes are responsible for NF fucosylation (Kaneko et al. 2011; Mergaert et al. 1997) and nodP and nod $Q$ genes are involved in their sulfation (Roche et al. 1991). It was shown that mutations in these four genes lead to an inability of rhizobia to trigger host responses or significantly decrease competitiveness to nodulate legume plants (Lamrabet et al. 1999; Snoeck et al. 2003; Wais et al. 2002). For example, the rate of nodule formation on Lotus japonicus roots exhibited by the nodP, nod $Q$ mutant of strain M. loti NZP-2235 was decreased by approximately 50\% compared with the wild type (Townsend et al. 2006).

\section{Symbiotic phenotype of the isolates M. japonicum Opo-242 and Bradyrhizobium sp. strain Opo-243.}

The symbiotic phenotype of isolates Opo-242 and Opo-243 was studied in a gnotobiotic plant nodulation assay with $O$. popoviana plants, using treatments of mono- and coinoculation. After 42 days of plant cultivation, the negative (uninoculated) control and plants inoculated with Opo-243 did not show any nodules, which was expected due to the absence of common nodABC genes in this strain. A simultaneous inoculation with strains Opo-242 and Opo-243 accelerated root nodule formation as compared with inoculation with a single strain, Opo-242. The first nodules appeared after 2 weeks, while isolate Opo-242 alone induced nodule formation only after 3 weeks (Fig. 6). The number of nodules significantly increased in the course of our experiment and stabilized after 4 weeks, in the case of coinoculation, and after 5 weeks when plants were inoculated with single Opo-242. It can be assumed that the presence of nolK, noe $L$, nodP and nod $Q$ genes in strain Opo-243 were involved in the modification of NFs and triggered the nodulation process. Apparently, strain Opo-242 synthesizes and excretes NFs, which are then modified outside the cells by another strain.

Pictures of nodules obtained in the gnotobiotic assay 2, 4, and 6 weeks after inoculation are presented in the Figure 1C through $\mathrm{H}$. The shape of nodules was round in the early stages (Fig. 1D and E) but, later on, they were more elongated with predominantly one branch (Fig. 1F through $\mathrm{H}$ ). An obvious difference in the size of nodules was found. Nodules formed by strain Opo-242 were about half as large as the nodules that appeared after inoculation with a mixture of strains Opo-242 and Opo-243. This phenomenon can be associated with an earlier formation of nodules in the coinoculation treatment.

Dry shoot and root biomass as well as the acetylene reduction activity measurements are given in Table 4 . Compared with the uninoculated control and inoculation with single nonnodulating strain Opo-243, strain Opo-242 significantly increased root biomass and acetylene reduction activity, while, after coinoculation with strains Opo-242 and Opo-243, all three parameters were statistically greater. There was also a tendency for an increase in dry shoot and root biomass (by 14 and 20\%, respectively) of plants inoculated with the strain mixture as compared with the strain Opo-242, however the differences were insignificant because of variation of the data. Even though the acetylene reduction measured at the end of experiments was similar in both variants with nodules (Opo-242 and Opo-242+ Opo-243), earlier nodule formation in the coinoculation treatment had some positive effect on plant growth.

The strains re-isolated from nodules, as estimated by $16 \mathrm{~S}$ rDNA sequencing, corresponded to those used for inoculation. The ratio of strain Opo-242 to Opo-243 in nodules was approximately 20 to 1 . It is yet unknown how isolate Opo-243 penetrated into nodules. However, it was shown that some Bradyrhizobium-related strains having no common nodABC genes infected tropical legume plants Aeschynomene spp. through epidermal fissures via the 'crack-entry' process (Giraud et al. 2007; Mornico et al. 2012; Okubo et al. 2013).

Thus, we demonstrated for the first time that the strains isolated from the same root nodule of the relict legume $O$. popoviana are co-microsymbionts having complementary sets of symbiotic genes and their simultaneous presence on roots increases the efficiency of host plant nodulation. The results obtained here are in agreement with previous reports (Safronova et al. 2014; 2015a and b; 2017b), suggesting that symbiotic systems of relict plants are archaic and can be formed with different rhizobial strains belonging to various taxonomic groups. It may be proposed that the phenomenon of low host specificity in the relict rhizobia-legume symbiotic systems allows infection with various bacteria related to plant-microbe symbiotic interactions and creates prerequisites for an effective exchange of genetic material between microsymbionts jointly inhabiting the root nodules. This hypothesis helps to explain evolution of rhizobia through the recruitment in one strain of a complete set of genes that are mandatory or promising for symbiosis but distributed over different bacterial taxa.

\section{MATERIALS AND METHODS}

\section{Isolation of rhizobial strains.}

Soil samples and seeds of $O$. popoviana were collected in the Baikal Lake region $\left(5^{\circ} 22^{\prime} 37.67^{\prime} \mathrm{N}, 1^{\circ} 6^{\circ} 28^{\prime} 24.06^{\prime \prime} \mathrm{E}\right.$, Buryatia). The content of available $\mathrm{P}$ was determined in $0.2 \mathrm{~N} \mathrm{HCl}$ soil extract (Watanabe and Olsen 1965), using a Smart Spec Plus spectrophotometer (Bio-Rad). The content of total $\mathrm{N}$ was determined by the Kjeldahl method, using a Kjeltec Auto 1030 analyzer (Tecator) according to the manufacturer's instructions. The total $\mathrm{C}$ was determined by the Tjurin's oxidation method (Arinushkina 1970). Seeds were surface-sterilized and scarified by treatment with $0.1 \% \mathrm{HgCl}_{2}$ for $10 \mathrm{~min}$ and, then, $5 \% \mathrm{NaOCl}$ for $8 \mathrm{~min}$, were rinsed carefully with sterile tap water, and were germinated on filter paper in petri dishes at $25^{\circ} \mathrm{C}$ in the dark for 4 days. Seedlings were transferred to three sterile plastic pots (one pot with five seeds) containing $250 \mathrm{~g}$ of soil. Plants were cultivated for 60 days in the growth chamber, with $50 \%$ relative humidity and four-level illumination/temperatures mode: night (dark, $\left.18^{\circ} \mathrm{C}, 8 \mathrm{~h}\right)$, morning $\left(200 \mu \mathrm{mol} \mathrm{m} \mathrm{m}^{-2} \mathrm{~s}^{-1}, 20^{\circ} \mathrm{C}, 2 \mathrm{~h}\right)$, day

Table 3. Presence of symbiotic genes in the isolates Mesorhizobium japonicum Opo-242 and Bradyrhizobium sp. strain Opo-243

\begin{tabular}{lllcc}
\hline & \multicolumn{3}{c}{ Genes } \\
\cline { 2 - 5 } Isolate & \multicolumn{1}{c}{ nod } & nif & fix & nol \\
\hline Opo-242 & $A B C D I J E F G N L M Z T$ & HDKENABQTZXWSU & ABCXNOPQGHISJKL & - \\
Opo-243 & $N T G[P Q]$ & {$[L] S$} & NOPQGHISJKL & $K$ \\
\hline
\end{tabular}

\footnotetext{
${ }^{a}$ Genes present in isolate Opo-243 and complementary to symbiotic genes of isolate Opo-242 appear in brackets.
} 
(400 $\left.\mu \mathrm{mol} \mathrm{m} \mathrm{m}^{-2} \mathrm{~s}^{-1}, 23^{\circ} \mathrm{C}, 12 \mathrm{~h}\right)$, evening $\left(200 \mu \mathrm{mol} \mathrm{m} \mathrm{m}^{-2} \mathrm{~s}^{-1}\right.$, $20^{\circ} \mathrm{C}, 2 \mathrm{~h}$ ). Illumination was performed by L $36 \mathrm{~W} / 77$ FLUORA lamps (Osram). Then, roots of individual plants were removed from soil and were washed with tap water. Pictures of plants and nodules were performed by the stereo microscope Stemi 508 (Zeiss) and the microscope color camera AxioCam ERc 5 s (Zeiss). Strains of nodule bacteria were isolated from the obtained nodules by the standard method described by Novikova and Safronova (1992), using modified yeast extract mannitol agar (Vincent 1970) supplemented with $0.5 \%$ succinate (Safronova et al. 2015a). All strains were deposited in the Russian Collection of Agricultural Microorganisms (WDCM 966) and were stored at $-80^{\circ} \mathrm{C}$ in the automated Tube Store (Liconic Instruments) as described previously (Safronova and Tikhonovich 2012).

\section{Whole-genome sequencing of isolates Opo-242 and Opo-243.}

Genomic DNA was extracted using the Genomic DNA purification kit (Thermo Scientific) according to the recommendation of the manufacturer. DNA was fragmented by the focused ultrasonicator Covaris S2 (Covaris). Fragment DNA libraries were prepared with NEBNext DNA library kit (NEB), and their quality was estimated with a High Sensitivity DNA kit on Bioanalyzer 2100 (Agilent). The DNA amount was estimated with a dsDNA high sensitivity kit on Qubit 1.0 (Invitrogen). Genome sequencing was performed on a MiSeq genomic sequencer (Illumina) by standard protocol with a MiSeq reagent kit, 600 cycles (Illumina) at the Siberian Branch of The Russian Academy of Sciences Genomics Core Facility (Institute of Chemical Biology and Fundamental Medicine). Genome was assembled de novo, using SPAdes 3.5.0 software (Bankevich et al. 2012). Quality control was performed by QUAST 3.0 (Gurevich et al. 2013). Search for genes in the assembled contigs was performed using the RAST annotation service (Overbeek et al. 2014). Search for homologs of the 16S rRNA gene, ITS region, housekeeping genes recA, glnII, and $r p o B$, as well as symbiotic genes in annotated genomes was performed, with CLC Genomics Workbench 7.5.1 software, using local BLASTn and tBLASTx.

Identification of isolates by analysis of the $16 \mathrm{~S}$ rDNA, ITS region, and housekeeping genes $\operatorname{rec} A, g \ln I I$, and $r p o B$.

For identification of all isolates, the following PCR primers were used: fD1 (5'-AGAGTTTGATCCTGGCTCAG-3') and rD1 (5'-CTTAAGGAGGTGATCCAGCC-3'), for an approximately 1,400-bp segment of the 16S rRNA gene (Weisburg et al. 1991). PCR was performed in 25- $\mu$ l reaction mixtures containing $150 \mu \mathrm{M}$ dNTPs (Promega), 5 pmol of each primer, $1 \mathrm{U}$ of Taq polymerase (Helicon), and 50 to $100 \mathrm{ng}$ of purified template DNA. PCR conditions for 16S rDNA amplification were as follows: initial denaturation at $95^{\circ} \mathrm{C}$ for $3 \min 30 \mathrm{~s}, 35$ cycles of denaturation at $94^{\circ} \mathrm{C}$ for $1 \mathrm{~min} 10 \mathrm{~s}$, annealing at $56^{\circ} \mathrm{C}$ for $40 \mathrm{~s}$, and extension at $72^{\circ} \mathrm{C}$ for $2 \mathrm{~min} 10 \mathrm{~s}$, final extension at $72^{\circ} \mathrm{C}$ for 6 min $10 \mathrm{~s}$. Electrophoresis was carried out with $1 \%$ agarose gel (Invitrogen) in Tris-acetate-EDTA. A 100-bp GeneRuler and Lambda DNA/HindIII markers (Fermentas) were used for sizing and approximate quantification of DNA fragments. $\mathrm{Pu}-$ rification of the PCR products was usually performed by using PureLink Quick kit (Invitrogen) according to the manufacturer's guidance. The direct sequencing of PCR products was performed on an ABI PRISM 3500xl genetic analyzer (Applied Biosystems) in the Core Centrum 'Genomic Technologies, Proteomics and Cell Biology' at the All-Russia Research Institute for Agricultural Microbiology.

Additionally, for identification of slow-growing isolate Opo243 , the ITS region as well as housekeeping genes $r e c A, g \ln I$, and $r p o B$, obtained from the whole-genome sequence, were analyzed. The sequences were compared with related sequences of the type strains available in the GenBank database, using BLAST analysis (Basic logical alignment search tool) at the National Center for Biotechnology Information. The Rrs dendrogram and the phylogenetic tree based on the concatenated $r e c A, g \ln I I$, and $r p o B$ sequences were constructed, using the neighbor-joining method, in the MEGA 5.0 software package (Tamura et al. 2011). The evolutionary distances were computed using the maximum composite likelihood method. Bootstrap analysis with 1,000 replicates was performed to estimate the support of clusters.

\section{Plant nodulation assay.}

Seeds were surface-sterilized, scarified, and germinated as described above. The uniformly germinated seedlings were transferred to polypropylene pots (Duchefa) containing $20 \mathrm{~g}$ of vermiculite (15 pots with two seeds per each treatment). Each pot was supplemented with $40 \mathrm{ml}$ of the nutrient solution (grams per liter): $\mathrm{K}_{2} \mathrm{HPO}_{4} 1.0, \mathrm{KH}_{2} \mathrm{PO}_{4} 0.25, \mathrm{MgSO}_{4}$ 1.0, $\mathrm{Ca}_{3}\left(\mathrm{PO}_{4}\right)_{2}$ 0.2, $\mathrm{FeSO}_{4} 0.02, \mathrm{H}_{3} \mathrm{BO}_{3} 0.005,\left(\mathrm{NH}_{4}\right)_{2} \mathrm{MoO}_{4}$ 0.005, $\mathrm{ZnSO}_{4} \cdot 7 \mathrm{H}_{2} \mathrm{O} 0.005, \mathrm{MnSO}_{4}$ 0.002. Pots were inoculated with isolates either Opo-242, Opo-243, or their combination in the amount of $10^{6}$ cells per pot. The uninoculated plants were used as negative control. Plants were cultivated for 42 days in the growth chamber, as described above. The number of nodules on six plants per treatment was counted 2, 3, 4, 5, and 6 weeks after planting. Nodules were photographed by the stereo microscope Stemi 508 (Zeiss). At the end of the experiments, the plants were dried at room temperature and the biomass of shoots and



Fig. 6. Nodule formation on Oxytropis popoviana roots after mono- and coinoculation with isolates Opo-242 and Opo-243 in the gnotobiotic plant nodulation assays. Vertical bars represent standard error. Asterisks indicate probability at $P<0.05(*), P<0.01(* *)$ and $P<0.001$ (***) (Student's $t$-test). The data of two experiments with six replications each is shown.

Table 4. Effects of mono- and coinoculation of Oxytropis popoviana plants with isolates Mesorhizobium japonicum Opo-242 and Bradyrhizobium sp. strain Opo-243 in the gnotobiotic plant nodulation assays ${ }^{\mathrm{a}}$

\begin{tabular}{|c|c|c|c|}
\hline Treatment & $\begin{array}{c}\text { Shoot } \\
\text { biomass } \\
\left(\text { mg DW }^{-1}\right. \\
\left.\text { plant }^{-1}\right)\end{array}$ & $\begin{array}{c}\text { Root } \\
\text { biomass } \\
(\text { mg DW } \\
\left.\text { plant }^{-1}\right)\end{array}$ & $\begin{array}{c}\text { Acetylene } \\
\text { reduction activity } \\
\left(\text { nmol }_{\mathbf{2}} \mathbf{H}_{4}\right. \\
\left.\text { plant }^{-1} \mathbf{h}^{-1}\right)\end{array}$ \\
\hline Uninoculated control & $2.2 \pm 0.3 \mathrm{a}$ & $0.7 \pm 0.2 \mathrm{a}$ & $0.1 \pm 0.02 \mathrm{a}$ \\
\hline Opo-243 & $2.3 \pm 0.2 \mathrm{a}$ & $0.6 \pm 0.1 \mathrm{a}$ & $0.1 \pm 0.01 \mathrm{a}$ \\
\hline Opo-242 & $2.8 \pm 0.2 \mathrm{ab}$ & $1.0 \pm 0.1 \mathrm{~b}$ & $2.1 \pm 0.4 b$ \\
\hline Opo-242 + Opo-243 & $3.2 \pm 0.3 b$ & $1.2 \pm 0.2 b$ & $2.3 \pm 0.3 b$ \\
\hline
\end{tabular}

a The strain Opo-243 did not produce nodules. The data is shown as mean \pm standard error of one representative experiment $(n=12)$. Different letters show significant differences between treatments (least significant difference test, $P<0.05)$. DW = dry weight. 
roots was weighed. Nitrogen fixation of nodules was measured by the acetylene-reduction method (Turner and Gibson 1980), using gas chromatograph GC-2014 (Shimadzu), at the end of the experiment. The experiment on nodulation assay was performed twice. Three nodules from each treatment were used for re-isolation of microsymbionts and their identification was performed by $16 \mathrm{~S}$ rDNA sequencing as descri above. The data were processed by the standard method of variance analysis, using the software STATISTICA version 10 (StatSoft Inc.). Fisher's least significant differences test and Student's $t$-test were used to evaluate differences between means.

\section{LITERATURE CITED}

Aoki, S., Ito, M., and Iwasaki, W. 2013. From $\beta$ - to $\alpha$-Proteobacteria: The origin and evolution of rhizobial nodulation genes nodIJ. Mol. Biol. Evol. 30:2494-2508.

Arinushkina, E. V. 1970. Guidance on Chemical Analysis of Soil. Moscow University Press, Moscow (in Russian).

Bankevich, A., Nurk, S., Antipov, D., Gurevich, A. A., Dvorkin, M. Kulikov, A. S., Lesin, V. M., Nikolenko, S. I., Pham, S., Prjibelski, A. D., Pyshkin, A. V., Sirotkin, A. V., Vyahhi, N., Tesler, G., Alekseyev, M. A. and Pevzner, P. A. 2012. SPAdes: A new genome assembly algorithm and its applications to single-cell sequencing. J. Comput. Biol. 19:455-477.

Barrett, L. G., Bever, J. D., Bissett, A., and Thrall, P. H. 2015. Partner diversity and identity impacts on plant productivity in Acacia-rhizobial interactions. J. Ecol. 103:130-142.

De Meyer, S. E., Tan, H. W., Andrews, M., Heenan, P. B., and Willems, A. 2016. Mesorhizobium calcicola sp. nov., Mesorhizobium waitakense sp. nov., Mesorhizobium sophorae sp. nov., Mesorhizobium newzealandense sp. nov. and Mesorhizobium kowhai sp. nov. isolated from Sophora root nodules. Int. J. Syst. Evol. Microbiol. 66:786-795.

Delamuta, J. R., Ribeiro, R. A., Ormeño-Orrillo, E., Melo, I. S., MartínezRomero, E., and Hungria, M. 2013. Polyphasic evidence supporting the reclassification of Bradyrhizobium japonicum group Ia strains as Bradyrhizobium diazoefficiens sp. nov. Int. J. Syst. Evol. Microbiol. 63:3342-3351.

Dos Santos, P. C., Fang, Z., Mason, S. W., Setubal, J. C., and Dixon, R. 2012. Distribution of nitrogen fixation and nitrogenase-like sequences amongst microbial genomes. BMC Genomics 13:162.

Edgren, T., and Nordlund, S. 2004. The fixABCX genes in Rhodospirillum rubrum encode a putative membrane complex participating in electron transfer to nitrogenase. J. Bacteriol. 186:2052-2060.

Fischer, H.-M. 1994. Genetic regulation of nitrogen fixation in Rhizobia. Microbiol. Rev. 58:352-386.

Giraud, E., Moulin, L., Vallenet, D., Barbe, V., Cytryn, E., Avarre, J. C., Jaubert, M., Simon, D., Cartieaux, F., Prin, Y., Bena, G., Hannibal, L., Fardoux, J., Kojadinovic, M., Vuillet, L., Lajus, A., Cruveiller, S., Rouy, Z., Mangenot, S., Segurens, B., Dossat, C., Franck, W. L., Chang, W. S., Saunders, E., Bruce, D., Richardson, P., Normand, P., Dreyfus, B. Pignol, D., Stacey, G., Emerich, D., Verméglio, A., Médigue, C., and Sadowsky, M. 2007. Legumes symbioses: Absence of Nod genes in photosynthetic bradyrhizobia. Science 316:1307-1312.

Gurevich, A., Saveliev, V., Vyahhi, N., and Tesler, G. 2013. QUAST: Quality assessment tool for genome assemblies. Bioinformatics 29:1072-1075.

Kaneko, T., Maita, H., Hirakawa, H., Uchiike, N., Minamisawa, K., Watanabe, A., and Sato, S. 2011. Complete genome sequence of the soybean symbiont Bradyrhizobium japonicum strain USDA6 ${ }^{\mathrm{T}}$. Genes (Basel) 2:763-787.

Kenicer, G., Smýkal, P., Vishyakova, M., and Mikić, A. 2009. Vavilovia formosa, an intriguing Pisum relative. Grain Legumes 51:8-12.

Lamrabet, Y., Bellogín, R. A., Cubo, T., Espuny, R., Gil, A., Krishnan, H. B., Megias, M., Ollero, F. J., Pueppke, S. G., Ruiz-Sainz, J. E., Spaink, H. P., Tejero-Mateo, P., Thomas-Oates, J., and Vinardell, J. M. 1999. Mutation in GDP-fucose synthesis genes of Sinorhizobium fredii alters Nod factors and significantly decreases competitiveness to nodulate soybeans. Mol. Plant-Microbe Interact. 12:207-217.

Lopez-Lara, I. M., and Geiger, O. 2001a. The nodulation protein NodG shows the enzymatic activity of an 3-oxoacyl-acyl carrier protein reductase. Mol. Plant-Microbe Interact. 14:349-357.

Lopez-Lara, I. M., Kafetzopoulos, D., Spaink, H. P., and Thomas-Oates, J. E. 2001b. Rhizobial NodL $O$-acetyl transferase and NodS $N$-methyl transferase functionally interfere in production of modified Nod Factors. J. Bacteriol. 183:3408-3416.

Malyschev, L. I. 2006. Flora of Siberia. Vol. 9, Fabaceae (Leguminosae). CRC Press, Boca Raton, LA, U.S.A.
Martínez-Hidalgo, P., Ramírez-Bahena, M. H., Flores-Félix, J. D., Igual, J. M., Sanjuán, J., León-Barrios, M., Peix, A., and Velázquez, E. 2016. Reclassification of strains MAFF $303099^{\mathrm{T}}$ and R7A into Mesorhizobium japonicum sp. nov. Int. J. Syst. Evol. Microbiol. 66:4936-4941.

Mergaert, P., van Montagu, M., and Holsters, M. 1997. The nodulation gene nolK of Azorhizobium caulinodans is involved in the formation of GDPfucose from GDP-mannose. FEBS Lett. 409:312-316.

Mornico, D., Miché, L., Béna, G., Nouwen, N., Verméglio, A., Vallenet, D. Smith, A. A., Giraud, E., Médigue, C., and Moulin, L. 2012. Comparative genomics of Aeschynomene symbionts: Insights into the ecological lifestyle of nod-independent photosynthetic bradyrhizobia. Genes (Basel) 3:35-61.

Novikova, N., and Safronova, V. 1992. Transconjugants of Agrobacterium radiobacter harbouring sym genes of Rhizobium galegae can form an effective symbiosis with Medicago sativa. FEMS Microbiol. Lett. 93 261-268.

Okubo, T., Fukushima, S., Itakura, M., Oshima, K., Longtonglang, A., Teaumroong, N., Mitsui, H., Hattori, M., Hattori, R., Hattori, T., and Minamisawa, K. 2013. Genome analysis suggests that the soil oligotrophic bacterium Agromonas oligotrophica (Bradyrhizobium oligotrophicum) is a nitrogen-fixing symbiont of Aeschynomene indica. Appl. Environ. Microbiol. 79:2542-2551.

Overbeek, R., Olson, R., Pusch, G. D., Olsen, G. J., Davis, J. J., Disz, T., Edwards, R. A., Gerdes, S., Parrello, B., Shukla, M., Vonstein, V., Wattam, A. R., Xia, F., and Stevens, R. 2014. The SEED and the rapid annotation of microbial genomes using subsystems technology (RAST). Nucleic Acids Res. 42:D206-D214.

Perret, X., Staehelin, C., and Broughton, W. J. 2000. Molecular basis of symbiotic promiscuity. Microbiol. Mol. Biol. Rev. 64:180-201.

Provorov, N. A., and Vorobyev, N. I. 2011. Evolution of legume-rhizobium symbiosis for an improved ecological efficiency and genotypic specificity of partner interactions. Genetika 47:417-424. (in Russian).

Roche, P., Debelle, F., Maillet, F., Lerouge, P., Faucher, C., Truchet, G., Denarie, J., and Prome, J. C. 1991. Molecular basis of symbiotic host specificity in Rhizobium meliloti: nodH and nodPQ genes encode the sulfation of lipooligosaccharide signals. Cell 67:1131-1143.

Safronova, V., Belimov, A., Andronov, E., Popova, J., Tikhomirova, N., Orlova, O., Verkhozina, A., Chimitov, D., and Tikhonovich, I. 2017a Method for obtaining root nodules of the Baikal relict legumes in laboratory pot experiments. Int. J. Environ. Stud. 74:700-705.

Safronova, V., Belimov, A., Sazanova, A., Kuznetsova, I., Popova, J., Andronov, E., Verkhozina, A., and Tikhonovich, I. 2017b. Does the MiocenePliocene relict legume Oxytropis triphylla form nitrogen-fixing nodules with a combination of bacterial strains? Int. J. Environ. Stud. 74:706-714.

Safronova, V., and Tikhonovich, I. 2012. Automated cryobank of microorganisms: Unique possibilities for long-term authorized depositing of commercia microbial strains. Pages 331-334 in: Microbes in Applied Research: Current Advances and Challenges. A. Mendez-Vilas, ed. World Scientific Publishing Co, Hackensack, NJ, U.S.A.

Safronova, V. I., Kimeklis, A. K., Chizhevskaya, E. P., Belimov, A. A., Andronov, E. E., Pinaev, A. G., Pukhaev, A. R., Popov, K. P., and Tikhonovich, I. A 2014. Genetic diversity of rhizobia isolated from nodules of the relict species Vavilovia formosa (Stev.) Fed. Antonie van Leeuwenhoek 105:389-399.

Safronova, V. I., Kuznetsova, I. G., Sazanova, A. L., Kimeklis, A. K., Belimov, A. A., Andronov, E. E., Pinaev, A. G., Chizhevskaya, E. P. Pukhaev, A. R., Popov, K. P., Willems, A., and Tikhonovich, I. A. 2015a Bosea vaviloviae sp. nov. a new species of slow-growing rhizobia isolated from nodules of the relict species Vavilovia formosa (Stev.) Fed. Antonie van Leeuwenhoek 107:911-920.

Safronova, V. I., Kuznetsova, I. G., Sazanova, A. L., Kimeklis, A. K., Belimov, A. A., Andronov, E. E., Pinaev, A. G., Pukhaev, A. R., Popov, K. P., Akopian, J. A., Willems, A., and Tikhonovich, I. A. 2015b. Extra slow-growing Tardiphaga strains isolated from nodules of Vavilovia formosa (Stev.). Fed. Arch Microbiol. 197:889-898.

Sinjushin, A. A., Demidenko, N. V., and Gostimskii, S. A. 2009. Preliminary report on taxonomical position of Vavilovia formosa (Stev.) Fed evidenced from morphological and molecular data. Pisum Genet. 41 15-20.

Snoeck, C., Verreth, C., Hernandez-Lucas, I., Martínez-Romero, E., and Vanderleyden, J. 2003. Identification of a third sulfate activation system in Sinorhizobium sp. strain BR816: The CysDN sulfate activation complex. Appl. Environ. Microbiol. 69:2006-2014.

Sprent, J. I., Ardley, J. K., and James, E. K. 2013. From North to South: A latitudinal look at legume nodulation processes. S. Afr. J. Bot. 89:31-41.

Tamura, K., Peterson, D., Peterson, N., Stecher, G., Nei, M., and Kumar, S. 2011. MEGA5: Molecular evolutionary genetics analysis using Maximum Likelihood, evolutionary distance, and Maximum Parismony methods. Mol. Biol. Evol. 28:2731-2739. 
Tikhonovich, I. A., and Provorov, N. A. 2007. Beneficial plant-microbe interactions. Pages 365-420 in: Comprehensive and Molecular Phytopathology. Y. T. Dyakov, V. Dzhavakhiya, and T. Korpela, eds. Elsevier, Amsterdam.

Tikhonovich, I. A., and Provorov, N. A. 2009. From plant-microbe interactions to symbiogenetics: A universal paradigm for the inter-species genetic integration. Ann. Appl. Biol. 154:341-350.

Townsend, G. E., Forsberg, L. S., and Keating, D. H. 2006. Mesorhizobium loti produces nodPQ-dependent sulfated cell surface polysaccharides. J. Bacteriol. 188:8560-8572.

Turner, G. L., and Gibson, A. H. 1980. Measurement of nitrogen fixation by indirect means. Pages 111-138 in: Methods for evaluating biological nitrogen fixation. F. J. Bergensen, ed. Wiley, Toronto, Canada.

Turuta, O., Ryabtsev, V., Novitskaya, N., and Vakarenko, L. 2015. Protected microhabitats as a part of Baikal regional ecological network. Plant
Microreserves the Site Based Plant Conservation And Monitoring Network, Irkutsk, Russia. http://cretaplant.biol.uoa.gr/docs/Turuta2001. pdf.

Vincent, J. M. 1970. A manual for the practical study of root nodule bacteria. Pages 73-97 in: IBP Handbook. Blackwell Scientific Publications, Oxford.

Wais, R. J., Keating, D. H., and Long, S. R. 2002. Structure-function analysis of Nod factor-induced root hair calcium spiking in Rhizobiumlegume symbiosis. Plant Physiol. 129:211-224.

Watanabe, F. S., and Olsen, S. R. 1965. Test of an ascorbic acid method for determining phosphorus in water and $\mathrm{NaHCO} 3$ extracts from soil. Soil Sci. Soc. Am. J. 29:677-678.

Weisburg, W. G., Barns, S. M., Pelletier, D. A., and Lane, D. J. 1991. 16S ribosomal DNA amplification for phylogenetic study. J. Bacteriol. 173: 697-703. 